\title{
The Commandment 'Love your Neighbour as Yourself' in the Epistle of James Július Pavelčík
}

\begin{abstract}
The Old Testament commandment 'love your neighbour as yourself' (Leviticus 19:18, further referred to as the commandment to love one's neighbour as well) has an indisputably privileged position among other commandments not only in Jesus' teachings but also in Paul's ethical challenges, as well as in the Epistle of James. The commandment is found in the individual New Testament books in various contexts. These, in a specific way, emphasise its extraordinary importance in the life of early Christian communities. This study deals with the interpretation of the commandment to love one's neighbour in the Epistle of James (2:8). Its specific concept is fundamentally conditioned by both contextual coherence and terminology and phrases which surround this interpretation and which are associated with various interpretive difficulties of linguistic, semantics, and theological character. The commandment to love one's neighbour as yourself is presented here as the norm that provides the Jewish-Christian addressees of the letter with guidance. It concerns the process of deciding on the practical implementation of the individual requirements of the Torah in the context of faith in the Lord Jesus Christ.
\end{abstract}

Keywords: Epistle of James, law, commandments, love, neighbour

\section{Introduction}

The commandment of love from Leviticus 19:18 is found in the New Testament eight times (Matthew 5:43; 19:19; 22,39; Mark 12:31,33; Luke 10:27; Romans 13:9; Galatians 5:14; James 2:8). This makes this commandment the most often directly quoted Old Testament text in the New Testament. In all places, it is stated in connection with the $\mathrm{Law}^{1}$ or other commandments of the Ten Commandments. ${ }^{2}$ The various contexts of the Synoptics, Paul, and James confirm and emphasise its undeniable and extraordinary importance in the life of early Christian communities. The importance concerns especially the process of reflections upon the ways of the fulfilling of Old Testament commandments and prohibitions in the context of faith in Jesus Christ, the Son of

1 In this study, the term 'Law' is used as the Torah equivalent and the term 'law' is used to denote the conception of this quantity in the Epistle of James.

2 Cf. Pierre KEITH, La citation de Lv 19,18b en Jc 2,1-13, in: The Catholic Epistles and the Tradition, ed. Jacques SCHLOSSER, Leuven: Peeters, 2004, p. 234. 
God and the Messiah.

In this study, we are interested in the way of presenting this commandment in the Epistle of James. Attention will first be paid to its contextual setting within the pericope 2:1-13. The content of this pericope is richness (verses 1-7) connected with the theme of the law (verses $8-13$ ). We will also explore other contextual coherence within the epistle. In the following sections, the individual segments of the eighth verse of the second chapter will be discussed. There are various interpretive difficulties of a linguistic, semantic, and theological nature. Their clarification will allow us to gain an idea of the position of the commandment to love one's neighbour in the environment of the Jewish-Christian community to which the Epistle of James is addressed.

\section{Text and Translation}

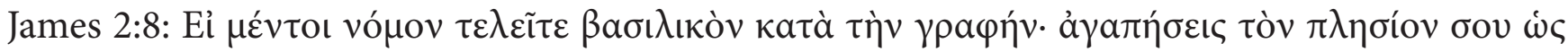

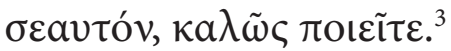

'If you really fulfil the royal law according to the Scripture, "You shall love your neighbour as yourself", you are doing well.'

\section{Context}

The commandment to love one's neighbour is a part of a broader text unit of James 2:1-13. There is quite a fundamental agreement in the literature about the definition of this text. The text itself is usually further divided into two interconnected basic parts: 2:1-7 and 2:8-13. Even if there is the significant presence of the 'law' at first sight in 2:1-13, its overarching theme is a certain appropriate action which corresponds to the faith in the Lord Jesus Christ (cf. 2:1). ${ }^{5}$

In verses $8-13$, there is a clear dominance of the subject of the law. This is mainly due to five of the ten occurrences of the word vómo in the Epistle of James $(1: 25 ; 2: 8,9,10,11,12$; 4:11 (four times)). The direct quotation of the commandment to love one's neighbour, together with the two quoted commandments (more precisely the prohibitions of the Ten Commandments in verse 11), give a specific character to a group of verses $8-11$ which can be easily distinguished from their immediate context by vocabulary and syntax..$^{6-7}$

None of the cited commandments, in its content, corresponds directly to the author's accusation about the preference of some people which is in the introductory verse of the second chapter. ${ }^{8}$ While in verses $1-7$, the contrast between rich and poor comes to the fore (or rather between showing respect and disrespect to them), verses 8-11 are based on the contrast between those who keep the law and those who transgress it ( vs. $\pi \alpha \rho \alpha \beta \dot{\alpha} \tau \eta \varsigma)$. The difference between the two paragraphs is also in the style: the rhetorical

3 The Greek text of the New Testament is from z Novum Testamentum Graece, 28. vyd., eds. Barbara ALAND et al., Stuttgart: Deutsche Bibelgesellschaft, 2012; the Greek text of the Old Testament is from Septuaginta: Id est Vetus Testamentum graece iuxta LXX interpretes, ed. Alfred RAHLFS, duo volumina in uno, Stuttgart: Deutsche Bibelgesellschaft, 1979.

5 This is shown by the broadly elaborated topic of unwanted preference of persons in verses 1-7 as well as by the actions described in

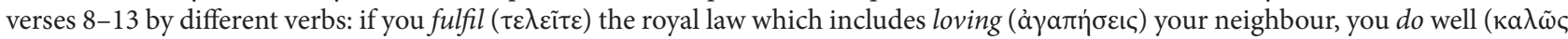

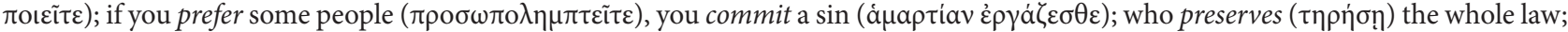

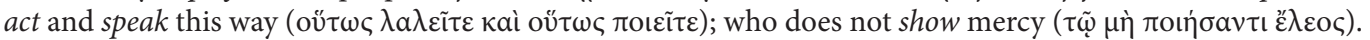

6 The term si $\mu \varepsilon \dot{v} \tau$ Tol and the connection of verses 8 and 9 one can see below. The conjunction $\gamma \alpha \dot{\rho}$ in verses 10 and 11 forms a close causal connection with the previous verses.

7 Cf. KEITH, La citation..., p. 241.

8 Ibid. 
questions in verses $4-7^{9}$ (addressing directly the addressees in the 2 nd person plural) are in verses 8-11 replaced by argumentation in the form of conditional sentences (the 2 nd person plural and the 3rd person singular are alternating there) which are connected by causal conjunctions. ${ }^{10}$ The specific thinking and actions which are typical of a group of addressed persons are replaced by more general ${ }^{11}$ statements of a moral nature based on the norms of the Law in the Scriptures of the Old Testament. ${ }^{12}$ Verses 1-7 express a negative aspect of the criticism of the addressees. It is directed against the bad attitude concerning favouring which is incompatible with their faith in Jesus Christ. In verse 8, the author formulates the positive side of his religious argument. He presents the implementation of the 'royal law according to Scripture' as an alternative. It is done in a manner corresponding to the commandment to love one's neighbour ${ }^{13}$ which is incompatible with the criticised favouring of the rich people. Verses 9-10 present this favouring as a sinful act and a transgression of the law. Any 'stumbling' ( $\pi \tau \alpha i \sigma \eta\rceil j \delta \dot{\varepsilon} \dot{\varepsilon} v \dot{\varepsilon} v i$ ) in connection with the law

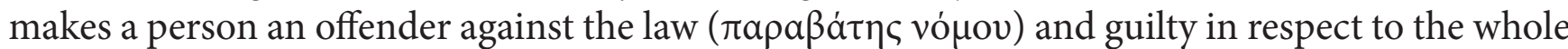

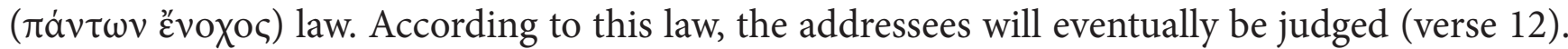
For the sake of completeness, it should be added that the attitude of the community towards both the rich and the poor is, according to the author, in direct conflict not only with the attitude of God himself (verses 5-6a) but also with their own experience with rich people. The rich are the ones who, according to the description in verses $2: 6 \mathrm{~b}-7$, have a negative attitude towards the addressees. They oppress them, drag them into the courts and blaspheme the good name called upon them. ${ }^{14}$

Naturally, the important connection between the two parts cannot be neglected. The connection is done through the terms expressing favouring on the basis of external appearance (verse 1:

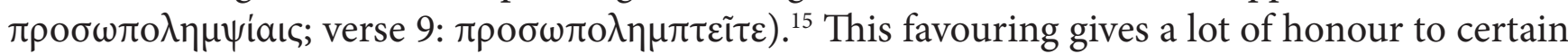
persons and denies it to others for reasons which have nothing to do with their real merits. At the same time, such actions contradict faith in Jesus Christ (verse 1). The addressees of the epistle

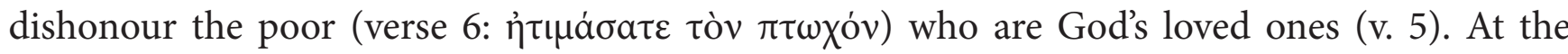
same time, they give service to the rich (v. 3). The topic of favouring is in verses 8-11 explicitly connected with the topic of the law. ${ }^{16}$

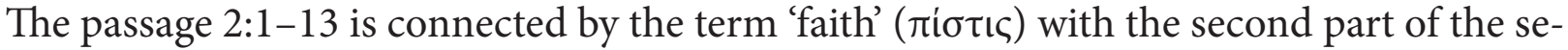
cond chapter (2:14-26) where the relationship between faith and deeds is themed. Faith is

9 Verse 4 is grammatically an apodosis of an extensive conditional sentence, and its protasis includes verses 2-3.

10 Rainer METZNER, Der Brief des Jakobus, Leipzig: Evangelische Verlagsanstalt, 2017, pp. 126-127: '8 öffnet um den Begriff vó $\mu$ o (...) kreisenden Gedankengang, der nicht mehr fragend, sondern lehrend argumentiert (erste Schriftzitate 2,8.11).'

11 Christoph BURCHARD, Nächstenliebegebot, Dekalog und Gesetz in the Epistle of James 2:8-11, in: Die Hebräische Bibel und ihre zweifache Nachgeschichte (FS R. Rendtorff), eds. Erhard BLUM, Christian MACHOLZ and Ekkehard W. STEGEMANN, NeukirchenVluyn, 1990, p. 525: 'Tatsächlich besprechen V. 8ff. wohl nicht mehr das Beispiel, sondern greifen das allgemeine Verbot V. 1 wieder auf.'

12 Luke L. CHEUNG, The Genre, Composition and Hermeneutics of James, Carlisle, Cumbria, U. K.: Paternoster Press, 2003, p. 97: 'Our author is here setting off a scriptural argument against the practise of favouritism.' Wiard POPKES, Der Brief des Jakobus, Leipzig: Evangelische Verlagsanstalt, 2001, p. 154: 'Der Abschnitt V. 8-13 ist somit viel grundsätzlicher, sozusagen bibeldogmatischer gehalten als der vorige.'

13 Cf. Ingeborg MONGSTAD-KVAMMEN, Toward a Postcolonial Reading of the Epistle of James: James 2:1-13 in its Roman Imperial Context, Leiden/Boston: Brill, 2013, p. 177.

14 METZNER, Brief..., pp. 109-110: 'Der Verzicht auf parteiisches Verhalten wird in 2,2-4 an einem Beispiel erläutert und anschließend theologisch begründet: Bevorzugung der Reichen widerspricht der göttlichen Erwählung der Armen (2,5-7 fragender Teil), dem Gebot der Nächstenliebe (2,8-11 lehrhafter Teil) und der Barmherzigkeit, deren Unterlassen ein erbarmungsloses Gericht nach sich zieht (2,12-13 mahnender Teil).

15 More about translation of these terms is in Ladislav TICHÝ, Slovník novozákonní rečtiny, Olomouc: Burget, 2001, p. 148; Helena PANCZOVÁ, Grécko-slovenský slovník od Homéra po krestanských autorov, Bratislava: Lingea, 2012, p. 1069.

16 METZNER, Brief..., pp. 126-127: 'Das Thema 'Parteilichkeit' wird nicht verlassen, sondern mit dem Gesetz in Beziehung gesetzt: Nächstenliebe verbietet Ungleichbehandlung.' 
dead ( $v \varepsilon \kappa \rho a ́, ~ 2: 17,26)$, or 'inactive' (à $\rho \gamma \eta$ ' 2:20) unless accompanied by appropriate deeds. The deeds of the community which sides with the rich thus do not correspond to its faith or to the commandment to love one's neighbour. The latter is a decisive indicator of proper behaviour in accordance with the proclaimed faith. ${ }^{17}$

Verses 2:1-13 are connected with the immediately preceding text (1:26-27) through the term кó $\mu$ ос. This word is associated with an irreconcilable contrast between God and the world ${ }^{18}$ concerning the realisation of authentic religion (1:27), or the right attitude towards the poor (2:5) both in the life of the individual and in the life of the community. Based on this context, the topic of favouring the rich and despising the poor as manifestations of the mentality of the 'world' can be related to the care of widows and orphans (1:27). ${ }^{19}$ Both highlight and confirm the author's strong emphasis on the social aspects of community life and his interest in them (see also $2: 15-17 ; 5: 4){ }^{20}$ Through the term vó $\mu$ ç, the first part of the second chapter also refers to the 'perfect law of freedom' in 1:25. It is mentioned there in connection with the subject of listening and speaking. In this section, the author urges the addressees not only to be passive recipients of the word but also to be its active doers (1:19-25). Section 2:8-11 is also important in this context because it clarifies the content of the 'law. ${ }^{21}$ Verses 4:11-12, in addition to condemning slander, clearly identify God as 'the only Lawgiver and Judge', and are very important for an overall understanding of the 'law' in the Epistle of James.

\section{Verses $2: 8$ and 2:9}

The interrelationship of verses 8 and 9 , which show connections on several levels, deserves special attention. From a syntactic point of view, these are two conditional clauses connected by the

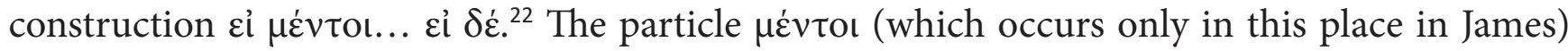
can have two basic meanings, namely (1) affirmative, confirming: 'really, indeed, for sure', and (2) adversely, contradicting: 'but, nevertheless. ${ }^{23}$ The following interpretation of the relationship between verses 8 and 9 supports the use of this particle in verse 8 in the first sense, although in all other places in the New Testament it seems to have a rather adverse meaning. ${ }^{24}$ In the sense of 'really', it then refers to what follows and it creates the transition to sub-section of verses $8-11 .{ }^{25}$

Verses 8 and 9 contain the inclusion created by the term 'law'. It stands as the normative quantity of action at the beginning of verse 8 , and as the judicial quantity that convicts of sin at the end of verse 9. The content of this inclusion in the mentioned verses forms an antithetical par-

17 Cf. MONGSTAD-KVAMMEN, Toward..., p. 178.



19 METZNER, Brief..., p. 110: „Wenn Jakobus vor einer die 'Armen' verachtenden Parteilichkeit warnt, nachdem es sich für 'Waisen und Witwen' eingesetzt hat, dann nimmt er einen traditionellen Zusammenhang auf." Gerhard MAIER, Der Brief des Jakobus, Witten: SCM R. Brockhaus; Giessen: Brunnen Verlag, 2. Auflage, 2009, p. 105: „Die Fürsorge für die Schwache bildete schon ein Thema für 1,26-27, jetzt setzt es sich in Ehrung und Barmherzigkeit gegenüber den Armen fort.“

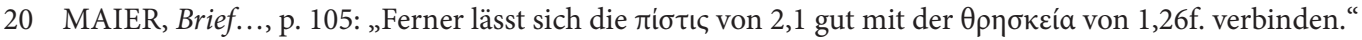

21 KEITH, La citation..., p. 232: „C’est aussi le seul passage de l’épître dans lequel l'auteur identifie des commandements qui appartiennent à cette Loi.“

22 Luke Timothy JOHNSON, The Use of Leviticus 19 in the Letter of James, Journal of Biblical Literature 3/1982, p. 400: 'Unquestionably, the $\mu \dot{\varepsilon} v \tau$ ol of v. 8 and the $\delta \dot{\varepsilon}$ of v. 9 must be seen as correlative.'

23 Cf. TICHÝ, Slovník..., p. 109; PANCZOVÁ, Slovník..., p. 808.

24 Cf. Dale C. ALLISON, A Critical and Exegetical Commentary on the Epistle of James, New York/London/New Delhi/Sydney: Bloomsbury, 2013, p. 401.

25 Cf. I-Jin LOH, Howard A. HATTON, A Handbook on the Letter from James, New York: United Bible Societies, 1997, p. 72; Rinaldo FABRIS, Legge della libertà in Giacomo, Brescia: Paideia, 1977, p. 67, comment 55. 


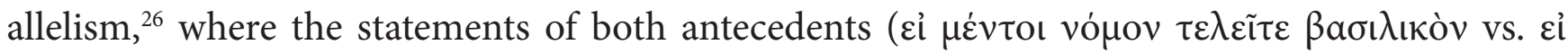

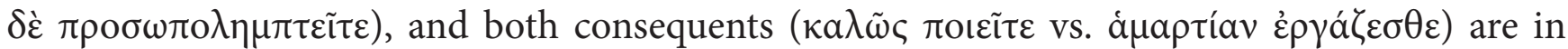
opposition. ${ }^{27}$ The sentences in both verses belong to the category of real conditional sentences whose relationship (through protasis) to reality is indeterminate; they express only the fact that the relationship between antecedent and consequent is real, respectively logically necessary. ${ }^{28}$ However, this leaves open the real status quo in the community on this issue. ${ }^{29}$ It is very likely that verse 9a refers to a real (not just a fictitious or hypothetical) case (cases?) of favouring the rich described in verses $2-4 .{ }^{30}$ Due to this fact, it can be concluded ${ }^{31}$ (if we take into account the contrasting nature of both verses) that verse $8 \mathrm{a}$ also describes reality, that is, that the addressed community in some way fulfils, or is able to fulfil, the royal law according to the commandment to love one's neighbour. The addressees, on the one hand, violate the law by their favouring the rich, but on the other hand, they are able to do good if they show love to their neighbours in some other way. ${ }^{32}$ This discrepancy does not surprise the reader of the epistle. It is, in essence, only one of the manifestations of ambivalence in the actions of the community. It is, though, fundamentally connected with the ambivalent relationship of the community with God. 'The community in the Epistle of James is divided in itself because it is not able to submit fully to God, God's will. They live a life full of compromise with the 'world', its reasoning, values, and norms (cf. 2:1-13; 4:1-3,13-16). ${ }^{33}$ The two described actions are thus not mutually exclusive on the basis of this consideration, and therefore it is possible to agree with the opinion (1) interpreting the two conditions as simultaneous in the sense that those who love their neighbour also favour the rich. According to this interpretation, the author of the epistle says that if the addressees although otherwise able to show love to their neighbours ${ }^{34}$ favour the rich, they are transgressors of the law in this one respect ( $\dot{\varepsilon} v \dot{\varepsilon} v$ í, verse 10$).{ }^{35}$ From a factual point of view, favouring the rich would be perceived more as a violation of the prohibition formulated in Leviticus 19:15 this is probably alluded to in verse $9 .{ }^{36}$ Although the commandment to love one's neighbour has a certainly more privileged position than the other commandments, it is neither in verse 8 nor anywhere in the

26 Cf. MONGSTAD-KVAMMEN, Toward..., p. 178; Franz MUSSNER, Der Jakobusbrief, Fünfte, durchgesehene Auflage, Freiburg/ Basel/Wien: Herder, 1987, p. 123; Douglas J. MOO, James: An Introduction and Commentary, Downers Grove, Illinois: IVP Academic; Nottingham, England: Inter-Varsity Press, 2007, p. 95.

27 Cf. KEITH, La citation..., pp. 242-243.

28 Cf. Heinrich von SIEBENTHAL, Griechische Grammatik zum Neuen Testament, Neubearbeitung und Erweiterung der Grammatik Hoffmann / von Siebenthal, Gießen und Basel: Brunnen, Basel: Immanuel, p. 201, par. 280c and 281; Friedrich BLASS, Albert DEBRUNNER and Friedrich REHKOPF, Grammatik des neutestamentlichen Griechisch, 17. Auflage, Göttingen: Vandenhoeck \& Ruprecht, 1990, par. 371, comment 1 .

29 The answer to this question quite fundamentally influences the interpretation, and therefore in the end it cannot be trivialised as it could be deduced, for example, from the following claim: MONGSTAD-KVAMMEN, Toward..., p. 179: 'However, whether the conditional sentences here are linked to real life or not, is actually not the most important aspect. The most important aspect is that the sentences in effect are saying this: a. Love your neighbour as yourself. b. Do not show partiality.'

30 For example ALLISON, Commentary..., p. 377: 'One doubts, however, that our text is only hypothetical. If an example is foreign to the readers' experience, its force diminished (...).

31 According to many other authors, however, only verse 9 is a reflection reality and verse 8 is purely hypothetical. ALLISON, Commentary..., p. 401, comment 221: 'This is the view of most commentators, who see partiality as contradicting love of neighbor.'

32 Cf. MONGSTAD-KVAMMEN, Toward..., pp. 178-179.

33 Blažej ŠTRBA et al., Emócie v Biblii. Výskum fenoménu emócií v biblickej tradícii, Bratislava: RKCMBF UK, 2018, p. 264. For more on the addressees' relationship to the 'world' see Július PAVELČÍK, Nábožnost' podla Jak 1,27, Studia theologica 2/2019, pp. 19-42.

34 Cf. Matt A. JACKSON-MCCABE, Logos and Law in the Letter of James. The Law of Nature, the Law of Moses and the Law of Freedom, Leiden; Boston; Köln: Brill, 2001, pp. 168-169; KEITH, La citation..., p. 243.

35 Gerd THEISSEN, Nächstenliebe und Egalität. Jak 2,1-13 als Höhepunkt urchristlicher Ethik, in: Petra v. GEMÜNDEN, Matthias KONRADT and Gerd THEISSEN, Der Jakobusbrief. Beiträge zur Rehabilitierung der „strohernen Epistel“, Münster: LIT, 2003, p. 128:

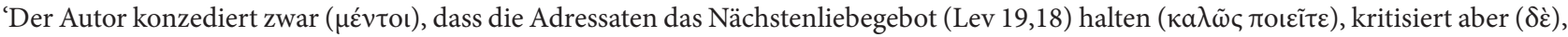
dass sie gegen das Gleichheitsgebot (Lev 19,15) verstoßen - um dann nachzuweisen, dass sie mit dem Bruch des einen Gebots das ganze Gesetz (und damit auch das Liebesgebot) verletzen.'

36 Cf. KEITH, La citation..., p. 243. 
Epistle of James identified with the 'law'. Therefore, it also seems to be the less convincing - otherwise major - second opinion (2). This interprets the conditional sentences in verses 8 and 9 as contradictory. ${ }^{37}$ It says that those who favour the rich transgress precisely and above all the commandment to love one's neighbour. ${ }^{38}$ This clarification ('above all') plays an important role here. The first opinion (which is used here) does not imply that the addressees do not sin against the commandment to love one's neighbour through their behaviour towards the rich (and the poor). According to it, they sin against the 'law'. In fact and in the first place, they sin against the prohibition of favouring someone (Leviticus 19:15), ${ }^{39}$ and thus also against the commandment to love one's neighbour. ${ }^{40}$ The very commandment of love is very broad in content. Subsequently, all regulations concerning interpersonal relationships can be applied to it in some way as the commandment represents a guiding or summarising principle. ${ }^{41}$

Another argument in favour of the abovementioned view (1) is a certain similarity between verses 8-9 and 10 and 11. According to verse 9b, those who favour the rich are convicted to be the trans-

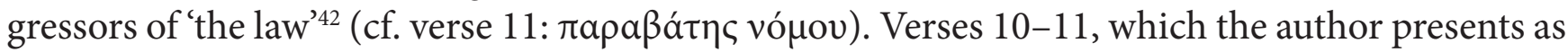
a justification for the statement or rather the accusation in verse 9, contain a certain variation of the abovementioned discrepancy, or inconsistency from verses 8-9 (understood as simultaneous conditions). ${ }^{43}$ A similar reasoning in these verses ${ }^{44}$ can be approached as follows.

(A) verses 8-9: favouring (the rich) is a transgression of the law even if one lives according to the normative directive of the law (namely the commandment to love one's neighbour) otherwise. ${ }^{45}$

(B) verse 10: transgression of the law in one respect makes a person guilty in all others, even if he otherwise keeps other parts of the law. ${ }^{46}$

(C) verse $11::^{47}$ the person who commits murder has become, a transgressor of the law even if he does not commit adultery, that is, he keeps the law in another respect.

Favouring the rich (associated here with the dishonouring of the poor) was one of the 'good morals' in Roman society at that time and was part of its etiquette. For the author of the epistle, however, it is unacceptable as it is not a matter of etiquette but law. 'Living according to Roman

37 For example, in one of the most recent comments METZNER, Brief..., p. 127: '2,9 hebt sich mit $\varepsilon$ í $\delta \dot{\varepsilon}$ adversativ von 2,8 ab. Das spricht

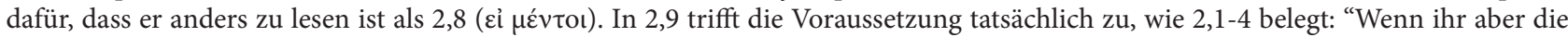
Person anseht (was der Fall ist), tut ihr Sünde". In 2,8 ist die Lage anders, denn Jakobus wird nach der bisherigen Kritik an liebloser

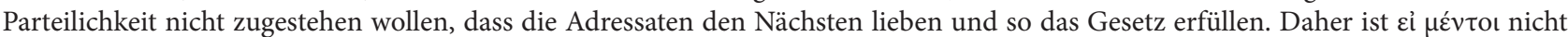
konfirmativ ( $\mu \varepsilon \dot{v}$-confirmativum) gemeint ("Wenn ihr in der Tat das königliche Gesetz erfüllt usw."), sondern zweifelnd-konzessiv: "Wenn ihr jedoch das königliche Gesetz erfüllt (was nicht der Fall ist) usw., tut ihr gut". 2,9 sagt, wie es ist, 2,8 wie es sein sollte.'

38 In this case, the commandment to love one's neighbour is presented according to KEITH, La citation..., p. 243 as 'l'unique commandement souverain de "la Loi royale".

39 Cf. below, p. 169.

40 Cf. THEISSEN, Nächstenliebe..., pp. 127-128.

41 Matthias KONRADT, The Love Command in Matthew, James, and Didache, in: Matthew, James, and Didache: Three Related Documents in TheirJewish and Christian Settings, ed. Huub van de SANDT and Jürgen K. ZANGENBERG, Atlanta: Society of Biblical Literature, 2008, p. 279: 'the love command formulates the basic intention or nature of the law, which is then explicated by other regulations.'

42 The definite article here does not refer to the commandment to love one's neighbour from verse 8 but to the 'royal law'. See Theißen, Nächstenliebe..., p. 128.

43 JACKSON-MCCABE, Logos..., p. 171: 'The correspondences between the two conditional statements of 2:8-9 and the complex conditions of 2:10 and 2:11 are in fact quite striking.

44 Cf. JACKSON-MCCABE, Logos ..., pp. 169-176; KEITH, La citation..., pp. 243-244.

45 JACKSON-MCCABE, Logos..., p. 174: 'Regardless of its possible summarizing function, "loving one's neighbor as oneself” is not, without further ado, simply equivalent to fulfilling the whole law in the Letter of James.'

46 BURCHARD, Nächstenliebegebot..., pp. 527-528: 'Dies (...), weil man die Autorität des ganzen Gesetzes bestreitet, wenn man ein

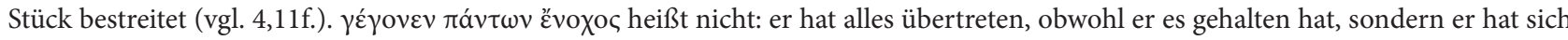
an der Würde des ganzen Gesetzes versündigt (vgl. 1 Kor 11,27).'

47 In this context, this verse can be understood as an illustrative example of the idea from the previous verse. See also KEITH, La citation..., p. 244. 
etiquette automatically makes you a sinner according to God's Law because Roman society is built upon partiality. What is acceptable in Roman society is unacceptable according to the Law of God. The Roman etiquette of partiality is an offence against God and a transgression of the love command. ${ }^{48}$ Favouring persons $(\pi \rho \circ \sigma \omega \pi \mathrm{o} \lambda \eta \mu \psi(\alpha)$ ) as the introductory theme of the second chapter is a transgression of the law (cf. 2:9,10) in several respects: it is not only a violation of the prohibition of favouring (Leviticus 19:15) but also a transgression against the commandment to love one's neighbour and transgression against the whole royal law.

\section{Fulfil the Royal Law}

'Law' (vó $\mu$ oc: $1: 25 ; 2: 8,9,10,11,12 ; 4: 11$ (four times)) is undoubtedly one of the most theologically relevant terms in the Epistle of James. ${ }^{49}$ It is discussed in three different contexts, always in the context of a certain action: ${ }^{50}$ the law and the practical implementation of the word (1:22-27), the law and the favouring of persons (2:1-13), and the law and slandering (4:11-12). ${ }^{51}$ In four cases it has different attributes: the 'perfect law of freedom' (1:25), 'royal law' (2:8), 'the whole law' (2:10), and 'the law of freedom' (2:12). These definitions identify three different aspects of the same law and together form its specific conception attributable to the Epistle of James. ${ }^{52}$ The 'law' in James's letter can, in some respects, be identified with the 'word' (cf. 1:18,21,22-25). ${ }^{53}$ This law expresses its imperative, normative and binding nature ${ }^{54}$ hence the perfect law of

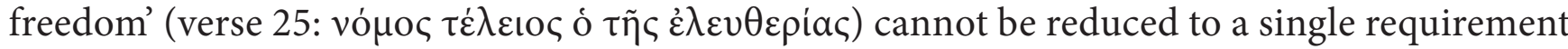
of the law. ${ }^{55}$ This is also confirmed in verse 2:10 where, through the wording 'the whole law'

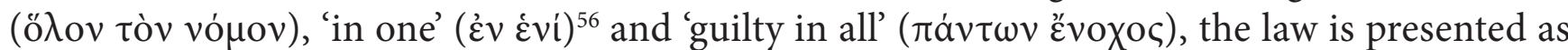
an organic unity. It is a unity 'where like in a living organism, the violation of one place disturbs the balance of the whole organism.'57 The law as a individual entity claims a certain authority through the process of 'convicting'. It acts as a judge and it is almost personified. ${ }^{58}$ The guarantor of the authority and organic integrity of the law and its individual parts ${ }^{59}$ is ultimately God himself as the only Lawgiver $(4: 12) .^{60}$

In connection with the characteristic of the 'royal' law ( $\beta a \sigma ı \lambda \iota k o$ $\varsigma)$ which is unique in the whole

48 MONGSTAD-KVAMMEN, Toward..., p. 189.

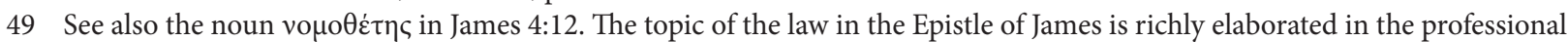
literature. See, for example, the references to the relevant literature in Július Pavelčík, „Dokonalý zákon slobody“ (Jak 1,25). K chápaniu zákona v Jakubovom liste, Studia Biblica Slovaca 2/2011, p. 175, notes 14, 15, and 16. In the following section, we will limit ourselves to those aspects of the law that are relevant to the interpretation of the relationship between the 'royal law' and the commandment to love one's neighbour.

50 William F. BROSEND, James and Jude, Cambridge: Cambridge University Press, 2004, p. 69: "Law," above all, is what members of the community are to "do."

51 BROSEND, James..., p. 68: 'In each case, James's use of law is subordinate - in support of - a point he is trying to make.'

52 Cf. MONGSTAD-KVAMMEN, Toward..., p. 179; PAVELČÍK, Zákon..., p. 175.

53 See in detail PAVELČÍK, Zákon..., pp. 176-185.

54 BURCHARD, Nächstenliebegebot..., p. 522: 'Der vó Taten fordert.'

55 Cf. Rudolf HOPPE, Der theologische Hintergrund des Jakobusbriefes, Würzburg: Echter Verlag, 1977, p. 89.

56 The dative $\dot{\varepsilon} v i$ should be understood as a neutrum which refers to one aspect, respectively to one part of the law. Cf. CHEUNG, Genre..., p. 121; HOPPE, Hintergrund..., p. 91; BURCHARD, Nächstenliebegebot..., pp. 527-528.

57 PAVELČÍIK, Zákon..., p. 206.

58 Cf. MONGSTAD-KVAMMEN, Toward..., p. 189; HOPPE, Hintergrund..., p. 90; Patrick J. HARTIN, James, Collegeville, Minnesota: Liturgical Press, 2003, p. 135.

59 MONGSTAD-KVAMMEN, Toward..., p. 192, note 327: 'The law is not only a series of individual commandments. The single commandments are all representative of the whole law.

60 Cf. CHEUNG, Genre..., p. 122; Stefan WENGER, Der wesenhaft gute Kyrios. Eine exegetische Studie über das Gottesbild im Jakobusbrief, Zürich: Theologischer Verlag, 2011, p. 152. 
New Testament, ${ }^{61}$ the following several possibilities of its interpretation can be considered: ${ }^{62}$

(1) It shows that the law comes from the king, it is a law issued by the king himself.

(2) It is related to the 'kingdom' mentioned in verse 5, it is the law related to this kingdom that is promised to those who love God.

(3) It characterises the royal, prominent position of the commandment of love among the other commandments.

(4) Unlike the previous one, the royal character includes not only one commandment but the whole law. This fact is based on its function or position.

(5) It applies to the addressees of the law who (when obeying this law) become not only heirs, or inhabitants of the kingdom, but kings themselves.

(6) Different combinations of previous interpretations.

Although the third interpretation (identifying the 'royal law' with the commandment to love one's neighbour) seems to be the majority, ${ }^{63}$ it can be considered the least likely. It is mainly because in all other places in the Epistle of James, the 'law' always means the whole law. ${ }^{64}$ This means that it cannot be reduced to one commandment no matter how more prominent than all the others it is. On the other hand, even if we do not accept it, we cannot deny a certain more privileged position of this commandment within the law even in the case of the remaining options. ${ }^{65}$ The other mentioned possibilities concerning the law as a whole are complementary $\mathrm{y}^{66}$ rather than mutually exclusive. This may be related to different levels of meaning of the adjective 'royal' itself. ${ }^{67}$ This adjective is left by the author of the epistle without further specification. Therefore, it is possible to formulate the characteristics of the 'royal' law. ${ }^{68}$ as, for example a law coming from God (cf. 4:12), from the King, it has royal dignity and authority, and is valid in his kingdom. ${ }^{69}$ In any case, the attribute 'royal' contains the idea of the highest position, the highest rank but also the perfection. In this way, it approaches the attribute of the law 'perfect' $(1: 25)^{70}$ and 'clearly underlines the importance of the vó $\mu$ os and so implies obligation to observe it. ${ }^{\text {' }}$

In connection with the transgression of the law, the two commandments of the Ten Commandments are explicitly given in 2:11 as concrete examples. It can be therefore rightly concluded that

61 Cf. MAIER, Brief..., pp. 116-117.

62 See overviews of various divisions where there are also references to the proponents of individual interpretations: for example, THEISSEN, Nächstenliebe..., pp. 132-134; WENGER, Kyrios..., p. 151; LOH and HATTON, A Handbook..., pp. 72-73; ALLISON, Commentary..., pp. 403-404; Hubert MEISINGER, Liebesgebot und Altruismusforschung. Ein exegetischer Beitrag zum Dialog zwischen Theologie und Naturwissenschaft, Freiburg, Schweiz: Universitätsverlag; Göttingen: Vandenhoeck und Ruprecht, 1996, pp. 137-138.

63 Similarly, Czech comments: František KOVÁ̌̌, Výklad listu Jakubova, Praha: Husova československá bohoslovecká fakulta, 1954, p. 37; František NOVÁK, List sv. Jakuba, Pardubice: nákladem vlastním, 1905, p. 37; Josef B. SOUČEK, Dělná víra a živá naděje. Výklad epištoly Jakubovy a první epištoly Petrovy, Praha: Kalich, 1968, p. 45; Jiří MRÁZEK, Bláznovství víry podle Jakuba: Výklad Jakubovy epištoly, Jihlava: Mlýn, 2006, pp. 48-49.

64 Cf. THEISSEN, Nächstenliebe..., p. 133.

65 Cf. MEISINGER, Liebesgebot..., p. 138; Sophie LAWS, A Commentary on the Epistle of James, London: Adam \& Charles Black, 1980 , p. 108.

66 See Wenger, Kyrios, 151; MEISINGER, Liebesgebot..., p. 138, note 31; THEISSEN, Nächstenliebe..., p. 134.

67 Cf. ALLISON, Commentary..., p. 405; JACKSON-MCCABE, Logos..., p. 154.

68 A very concise and dense characteristic is given by WENGER, Kyrios..., p. 156: 'Der vó $\mu$ oc ist die vom einen Gesetzesgeber, vom wesenhaft guten König geschenkte, inhaltlich auf das Gesetz der Nächstenliebe fokussierte (aber nicht darauf reduzierte) vollkommene Wegweisung, die (Christen-)Menschen einerseits zu entsprechendem Leben gegenüber dem darin explizierten Willen ihres kúpıoৎ verpflichtet und sie andererseits zum segensreichen Leben in Gottes Königreich freisetzt.'

69 The application of the adjective 'royal' to the addressees (mentioned in the fifth option) is not entirely unacceptable, but it is not entirely without problems either. CHEUNG, Genre..., p. 97: 'it is hard to understand why it is necessary in our author's argument to describe the law as 'for the kings' here.'

70 Cf. Ceslas SPICQ, Agapè dans le Nouveau Testament: analyse des textes I, Paris: J. Gabalda, 1958, p. 196.

71 ALLISON, Commentary..., p. 404. 
the 'law' as the main theme of sections 2:8-13 includes the law of Moses, the (whole) Torah. ${ }^{72}$ The law as a whole (2:10) is an expression of the will of the one God, the Lawgiver (4:12). At the same time, it is a norm of Christian ${ }^{73}$ action which is specifically formulated in the individual commandments of the law of Moses (cf. 2:10,11) and, eminently, in the commandment to love one's neighbour $(2: 8)$. The latter is inseparable from love for God. The commandment to love one's neighbour (which has a certain normative position, verse 8 ) $^{74}$ and the expression of mercy (which is a decisive factor in court, verse 13) frame the subject matter of the law in the second chapter of the epistle. It therefore serves as certain hermeneutic principles of the conception of law, the interpretation of law, as a "critical norm" with respect to the Torah. ${ }^{35}$ They thus provide the Jewish-Christian community of addressees with practical guidance. This concerns the process of deciding on the fulfilment ( $\tau \varepsilon \lambda \varepsilon i \tau \varepsilon)$ of the Torah and its requirements in the context of faith in Jesus Christ. The epistle of James represents the concept of the Torah interpreted in a Christian way. ${ }^{76} \mathrm{It}$ is also based on Jesus' interpretation of the Law. ${ }^{77}$

The verb $\tau \varepsilon \lambda \varepsilon \tilde{v} v$ with the basic meaning 'to complete 78 means (in connection with 'the law') 'to fulfil the law' in the sense of 'to do something to the fullest extent / completely' (cf., for example, Luke 2:39). ${ }^{79}$ At the forefront is the aspect of its deliberate and conscious practical implementation..$^{80}$ Therefore, in this context, it is also possible to use the translation 'to implement the law', or

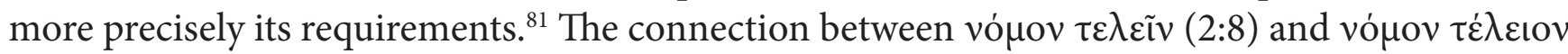

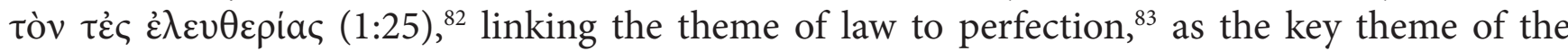
Epistle of James cannot be overlooked..$^{84}$ The 'perfect law of freedom' (1:25) is God's gift. It accompanies believers who should live according to it (vó $\mu$ ov $\tau \varepsilon \lambda \varepsilon i \tau \varepsilon, 2: 8)$ on their path to perfection

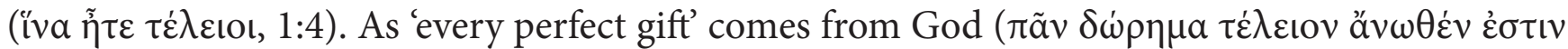

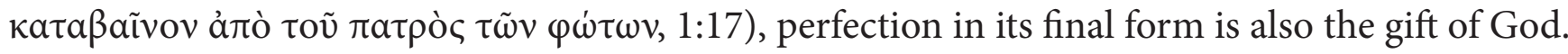

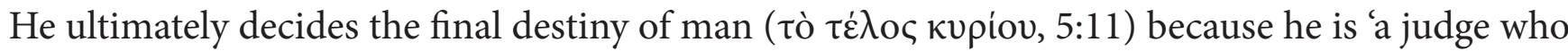

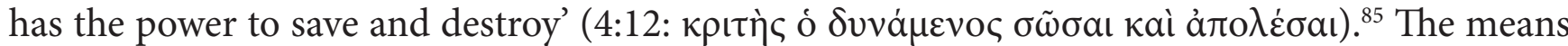
for the final assessment of human speaking and action is the law of freedom (2:12). The attribute

72 On the issue of the 'whole law' (verse 10), see in more detail PAVELČÍK, Zákon..., pp. 204-209.

73 In the Epistle of James, the law is spoken of in the context of 'faith in our Lord Jesus Christ' (James 2:1).

74 CHEUNG, Genre..., p. 123: 'Substantially, this whole law is not in any way different from the Mosaic law, but as to its significance and application, it is the royal law or the perfect law of liberty as summarised, interpreted and fulfilled through the love command.'

75 PAVELČÍK, Zákon..., p. 203. KEITH, La citation..., p. 243: 'le commandement de l'amour est un commandement important, mais non isolé. Son role correspondrait à celui d'un principe herméneutique, particulièrement adapté à la situation évoquées par l'auteur.' Cf. Hubert FRANKEMÖLLE, Gesetz im Jakobusbrief. Zur Tradition, kontextuellen Verwendung und Rezeption eines belasteten Begriffes, in: Das Gesetz im Neuen testament, ed. Karl KERTELGE, Freiburg im Breisgau/Basel/Wien: Herder, 1986, p. 214.

76 MAIER, Brief..., p. 117: 'Es kann überdies keine Frage sein, dass für Jakobus das Gesetz, messianisch = 'christlich' ausgelegt, seine Verbindlichkeit auch im Neuen Bund behält.'

77 Cf. Peter H. DAVIDS, The Epistle of James. A Commentary on the Greek Text, Grand Rapids, MI: Wm. B. Eerdmans Publishing Co., 1983, p. 114.

78 Frederick William DANKER, The Concise Greek-English Lexicon of the New Testament, Chicago and London: The University of Chicago Press, 2009, p. 350: "'bring to completion," of functioning in a manner that leaves nothing undone.'

79 DANKER, Lexicon..., p. 350: 'do (completely), of carrying out an action or objective to the fullest extent'.

80 Arnold G. FRUCHTENBAUM, Der Jakobusbrief, Hünfeld: CMD, 2014, p. 65: 'Das griechische Wort erfüllen bedeutet, etwas in die Praxis umzusetzen und das beabsichtige Ziel zu erreichen.'

81 Walter BAUER, Griechisch-deutsches Wörterbuch zu den Schriften des Neuen Testaments und der frühchristlichen Literatur, 6. völlig neu bearbeitete Aufl. im Inst. für Neutestamentliche Textforschung, Münster, unter bes. Mitwirkung von V. Reichmann, hrsg. Kurt ALAND and Barbara ALAND, Berlin - New York: de Gruyter, 1988, column 1617: 'die Forderungen des Gesetzes ausführen'.

82 ALLISON, Commentary..., pp. 401-402: 'Perhaps James has chosen the verb because of his interest elsewhere in $\tau \dot{\varepsilon} \lambda \varepsilon\left\llcorner O c^{\prime}\right.$. MEISINGER,

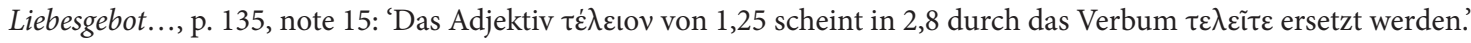

83 And indirectly also with other words with the root $\tau \varepsilon \lambda$-.

84 For more on the relationship between law and perfection, see PAVELČÍK, Zákon..., pp. 185-190.

85 Cf. PAVELČÍK, Zákon..., p. 190. 
of perfection and the attribute 'royal' related to God's 'kingdom' which, like the 'wreath of life' is promised to 'those who love God' $(2: 5 ; 1: 12)$, confirm and supplement the eschatological aspect of the law.

\section{According to the Scripture}

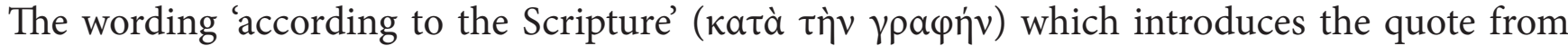
Leviticus 19:18, is the only one in the New Testament in this form. ${ }^{86}$ In the Epistle of James, it represents a very specific statement of a direct Old Testament quotation because in all other places $(2: 11,23 ; 4: 5,6)$, the author uses the forms of the verb $\lambda \dot{\varepsilon} \gamma \varepsilon \varepsilon v$ ('to say') for this purpose. The preposition katá in conjunction with the accusative itself has the meaning 'according to' in the sense of 'in accordance with' in other places in the Epistle (James 2:17:87 3:9). The phrase katà $\tau \eta े v \rho \propto \varphi \eta v$ is found in the Septuagint six times and always in the meaning according to, in accordance with' in the religious context (Deuteronomy 10:4; 1 Chronicles 15:15; 2 Chronicles 30:5; Ezra 6:18) or political context (2 Chronicles 35:4; 3 Ezra 1:4). In none of these cases does katà

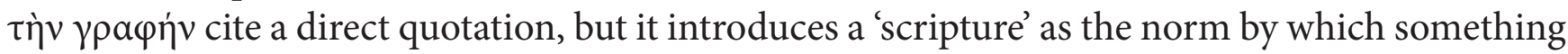
must be done. It therefore can be reasonably assumed that the author of the Epistle of James also used the above phrase in this normative sense: ${ }^{88}$ 'If you keep the royal law in accordance with the

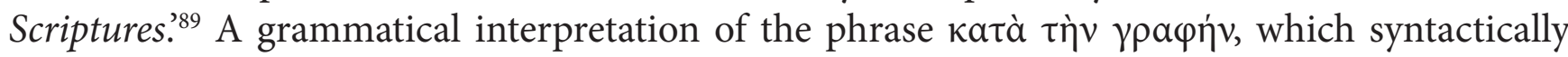
belongs to the verb $\tau \varepsilon \lambda \varepsilon \tilde{\tau} \tau \varepsilon$ and not to vó $\mu$ ov $\beta a \sigma ı \lambda \iota \kappa o ́ v$, is also associated with this interpretation and the abovementioned assertion of the impossibility of identifying the commandment to love one's neighbour with 'royal law.90 The whole 'royal law' is to be fulfilled in accordance with the commandment to love one's neighbour. ${ }^{91}$ It is also just one among the other Old Testament commandments but with a special status towards them as these are to be carried out according to it.

The unusual usage of the text from Scripture can perhaps also be seen as one of the ways in which the author suggests its special position in relation to other Old Testament commandments and prohibitions within the Ten Commandments. Two of them, cited in verse 11, are introduced by the aorist forms of the verb $\lambda \dot{\varepsilon} \gamma \omega$ indicating that they are simple quotations used as examples of the organic interconnection of the various parts of the 'whole Law' associated in verse 10 with the

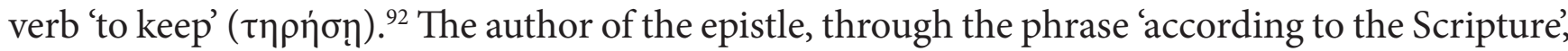
the connection with 'the fulfilment of the royal law', and the comment 'you do well', presents the commandment to love in its essential importance and normative function to Christians. ${ }^{93}$ This function comes from the status and authority attributed to the commandment in Jesus' teaching. ${ }^{94}$

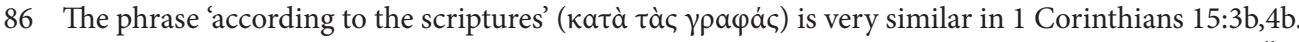

87 Here we most often encounter the translation '(faith) by itself' but as stated by Jacqueline ASSAËL and Élian CUVILLIER, L'Épitre de Jacques, Genève: Labor et Fides, 2013, p. 202: 'katá avec le réfléchi signifié plutôt: "selon sa propre nature”, d’où 'd’elle-même”.

89 Cf. PAVELČÍK, Zákon..., p. 202. This meaning of the phrase 'according to the Scripture' in James is also supported by the phrase 'according to the Scriptures' in 1 Corinthians 15:3b,4b. It does not give any specific quotation from the Old Testament but expresses that Jesus' death for our sins and his resurrection were in accordance with the testimony of the Old Testament Scriptures.

90 Cf. THEISSEN, Nächstenliebe..., p. 135; MEISINGER, Liebesgebot..., p. 136.

91 Cf. CHEUNG, Genre..., pp. 99-100.

92 KEITH, La citation..., pp. 241-242: 'Ces changements ne sont pas seulement l'expression d'un souci stylistique. Le verbe $\tau \varepsilon \lambda \dot{\varepsilon} \omega$ a une portée plus forte que le simple $\tau\rceil \rho \varepsilon ́ \omega$ utilisé au v. 10 (...) En Jc 2,8, la "Loi royale”, la norme suprême et souveraine, est "réalisée selon ce qui est écrit", et ce terme $(\tau \varepsilon \lambda \dot{\varepsilon} \omega)$ est à comprendre au sens fort d' "être portée à sa réalisation parfait".

93 Cf. KEITH, La citation..., pp. 231 and 234.

94 LAWS, Commentary..., p. 110: 'it is probable that when James quotes Lev. xix. 18 as scripture he does so in the knowledge that this scripture has received the added authority of Jesus' use.' 
The words 'according to the Scripture' explicitly represent the commandment to love as a normative part of Scripture, or of the Law (as shown in verses 8-11). The author of the Epistle of James (also) most likely knew and consciously used the Old Testament context of this commandment from Leviticus 19:12-18. ${ }^{95}$ Here (in the same way as in the abovementioned place of Leviticus) it is mentioned in connection with the prohibition of favouring. Leviticus 19:15, in the context of litigation, demands impartiality for both the poor and the powerful: 'You shall do no injustice in judgment; you shall not show partiality to the poor nor favouritism to the mighty; in righteousness

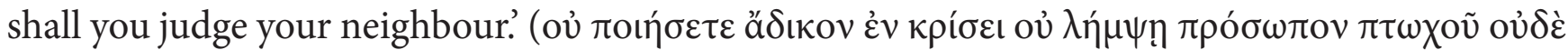

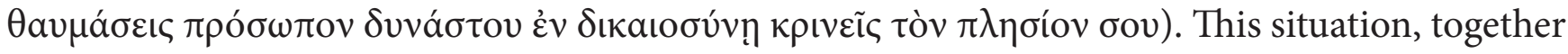
with the characteristics and position of the 'poor' in the second chapter ( $\pi \tau \omega \chi$ ó $\varsigma 2: 2,3,5,6)$, does not allow James to take over the position from Leviticus and also appeal to the impartiality of the poor; God himself favours them, he is on their side, and therefore one has to be on their side. ${ }^{96}$ This could also be one of the reasons ${ }^{97}$ why he does not quote Leviticus 19:15 explicitly. Although in James 2:1-13, unlike in Leviticus 19, no specific court case is dealt with, the whole pericope (in which the prohibition of favouring and the commandment to love one's neighbour are found) is full of judicial terminology. ${ }^{98}$

The author of the Epistle of James thus very closely connected the commandment to love one's neighbour and the prohibition of favouring persons more significant from a social point of view in a way, similarly as in Leviticus $19: 12-18 .{ }^{99}$ According to him, the commandment to love is the determining norm by which the whole law of Moses is to be kept and interpreted. Therefore, the violation of the prohibition of favouring persons is also a transgression against the commandment to love. ${ }^{100}$

\section{You Will Love Your Neighbour}

In the Epistle of James, in addition to the Old Testament quotation from Leviticus 19:15 which occurs in 2:8, the verb á $\gamma \alpha \pi \dot{\alpha} \omega$ occurs only two times, in 1:12 and 2:5, and its adjective derivative

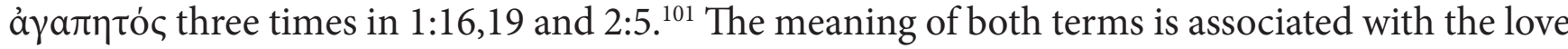
$\dot{\alpha} \gamma \dot{\alpha} \pi \eta^{102}$ which, like $\varphi \iota \lambda i \alpha$, refers primarily to 'love that arises on the basis of preference' but also (with the specific nuance) to 'love which can be directed through our decisions and reasoning. So preferences are based less on emotions and more on balance. ${ }^{103}$

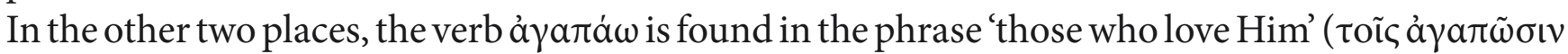
aủóv). Based on the context of 'he' in 2:5, God is evidently meant by this. In 1:12c, the subject of

95 Cf. JOHNSON, Use..., p. 399.

96 Otherwise THEISSEN, Nächstenliebe..., p. 126: 'Die Symmetrie der Unparteilichkeit in beide Richtungen ist eine der Pointe in Jak 2,1ff, auch wenn eine Begünstigung des Geringen, vor der in Lev 19,15 gewarnt wird, nicht im Blick ist'.

97 Others are considered, for example, by THEISSEN, Nächstenliebe..., p. 129: 'Vezichtet PsJakobus deshalb auf ein explizites Zitat von Lev 19,15, weil er das Gleichheitsgebot ganz eng mit dem Nächstenliebegebot verbinden will, um es so ins Zentrum des christlichen Ethos zu rücken? Will er sagen: Wer das Liebesgebot als Identitätsmerkmal der Christen ernst nimmt (was unumstritten ist), muss das Gleichheitsgebot ebenso ernst nehmen, da es die Kehrseite der Nächstenliebe ist?'

98 THEISSEN, Nächstenliebe..., pp. 126-127: 'Die Nächstenliebe wird im Jakobusbrief (wie in Lev 19) zwar eng mit forensischen Bildern verbunden, sie meinen hier aber metaphorisch das gegenwärtige ethische Urteil der Menschen, mythisch das zu erwartende Jüngste Gericht (Jak 2,12f). Forensisch ist vor allem das Gebot der Unparteilichkeit.'

99 Cf. also THEISSEN, Nächstenliebe..., pp. 129-130.

100 Cf. JOHNSON, Use..., p. 400.

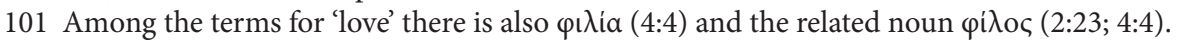

102 However, this noun is not found in James.

103 Veronika ČERNUŠKOVÁ, Tři stupně lásky v řeckém jazyce? Výrazy „milovat“ a „láska“ v klasické řecké literatuře a u církevních otců, Studia Theologica 1/2014, p. 27. LOH and HATTON, A Handbook..., p. 73: 'In this context the ideas of duty or loyalty are foremost, rather than the meaning "like someone very much". 
the verb $\dot{\varepsilon} \pi \eta \gamma \gamma \varepsilon$ i $\lambda \alpha \tau$ ('promised') is not explicitly stated but there can be no serious doubt that it is God (or the Lord). 'Love in the sense of $\dot{\alpha} \gamma \dot{\alpha} \pi \eta$ is here primarily an expression of the decision and focus of one's life, one's personality on God.' ${ }^{104}$ In addition to the quotation from Leviticus, the other two occurrences of the verb áyatáw refer to God. Although the commandment of love for God from Deuteronomy 6:5 is not quoted in the Epistle of James, ${ }^{105}$ it cannot be denied that the commandment to love one's neighbour is for its author associated with love for God. ${ }^{106}$

'Those who love God' are those who live according to his law, ${ }^{107}$ obey his law, and do not judge this law (cf. 4:11-12). In this context, the words from verses $2: 5$ and 1:12 about the eschatological promise of the kingdom (or of the wreath of life - 'to those who love God') are instructive for

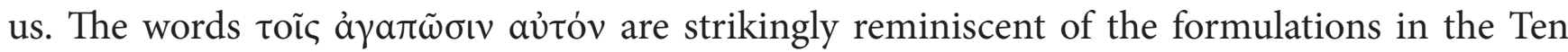
Commandments ${ }^{108}$ where God promises his mercy to a thousand generations of those who love

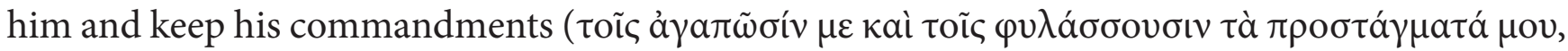
Exodus 20:6 and Deuteronomy 5:10). ${ }^{109}$ A similar explicit connection of love for God with the act of keeping his commandments can be seen in the Epistle of James where statements about the kingdom as a reward for those who love God (2:5) and about keeping the royal law, or the whole law $(2: 8,10)$ are immediately next to each other.

From some places in the Epistle of James, it is possible to read how (in the author's opinion) the love for God manifests itself or should manifest itself more specifically. 'Those who love God' are those who ask him correctly (cf. 4:2b-3); those who do not love the world and want to be friends

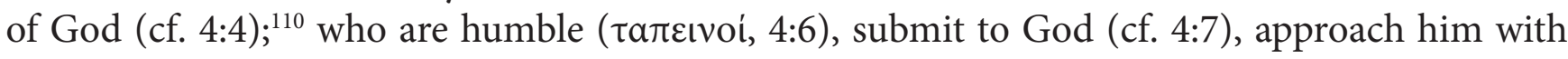
clean hands and a pure heart (4:8), humble themselves before the Lord, because only he can exalt them (4:10). The opposite of all this subverts the community, causes strife, envy, or jealousy, ${ }^{111}$ fights within the community (4:1-2) behind which is the 'drowning' in desires and pleasure (cf. $4: 1 \mathrm{~b}, 3 \mathrm{~b})$. They are also those who are the active recipients and doers of the word of salvation $(1: 22,21)$. By this word, God by the decision of his will gave birth to them to be heading to salvation living in the freedom of God's creatures (1:18). "Doing the word" is the answer to what God intended for man when he "planted" the "word" into him.'112 They are those who manifest 'pure and undefiled piety before God' by 'visiting the orphans and widows in their distress and keeping themselves from being unstained by the world' (1:27), those who praise not only the Lord and Father but also other people (3:9), ${ }^{113}$ those who avoid slandering of a brother or judgement of a neighbour (4:11-12), those who consider God as Lord over their lives when living and planning their future (4:15), and those who are patiently waiting for the coming of the Lord (cf. 5:7-11) and in any situation turn to him in prayer (5:13).

104 ŠTRBA, Emócie..., p. 247.

105 This is not surprising, because the direct quotation of Deuteronomy 6: 5 is found in the New Testament only in the Synoptics: Mark 12: 30, 33; Mathew 22:37; Luke 10:27.

106 See Ralph P. MARTIN, James, Waco, Texas: Word Books, 1988, p. 69. HOPPE, Hintergrund..., p. 89: 'Zusammen mit dem Gebot zur Nächstenliebe 2,8 kennt der Jak auch die Liebe zu Gott, vgl. 1,12; 2,5; gerade in diesen beiden Motiven realisiert sich das 2,1 geforderte

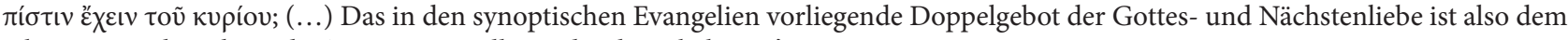
Jak, wenn auch nicht in der Zusammenstellung, durchaus bekannt.'

107 JACKSON-MCCABE, Logos..., p. 166: 'Love of God, while not, to my knowledge, explicitly cited as a summary of the law, is routinely used in Jewish literature as a shorthand expression for living in accord with the law.

108 JACKSON-MCCABE, Logos..., p. 166.



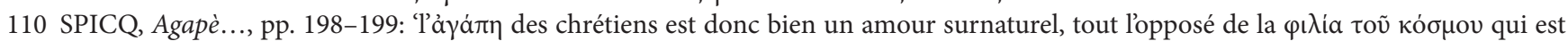
inimitié à l'égard de Dieu $(\mathrm{IV}, 4)$ '.

111 Cf. ŠTRBA, Emócie..., pp. 256-259.

112 PAVELČÍK, Zákon..., p. 184.

113 HOPPE, Hintergrund..., 89: 'wenn der Verfasser kritisiert, daß die Hörer mit demselben Mund Gott loben und der Mitmenschen verfluchen, 3,9f., dann steht dahinter der Gedanke, daß Gottes- und Nächstenliebe sich nicht widersprechen dürfen.' 
In verses 2:19 and 4:12, regarding the oneness of God, the Lawgiver and the Judge, echoes of Deuteronomy 6:4-5 can be recognised, where faith in the one God is inextricably linked with absolute devotion and love for Him. To love God 'with all your heart and with all your soul and

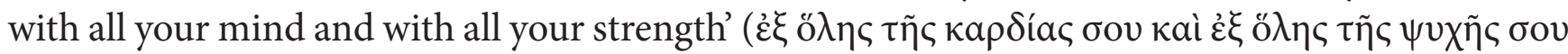

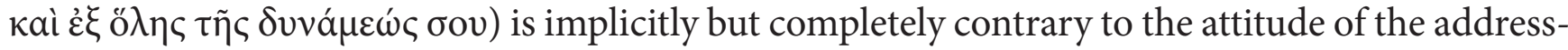
ees of the epistle who are divided in their relationship with God. The author of the letter clearly

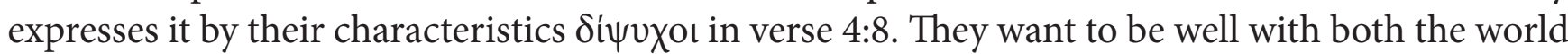
and God (see 4:4). ${ }^{114}$ The ambivalence in relation to God is also reflected in the interpersonal relationships within the community (see, for example, $2: 2-4,14-16 ; 3: 14-16 ; 4: 1-2,11 ; 5: 4,9$ ). This only confirms the urgency to guide them through life according to the law in accordance with the commandment to love one's neighbour.

As in all other places of the New Testament, where the commandment to love one's neighbour is quoted from Leviticus 19:18, with the exception of the Gospel of Luke (cf. Luke 10:29,36), the author of the Epistle of James does not clarify who is to be considered a neighbour. In his work (in addition to 2:8), he uses the term $\pi \lambda$ noíov in 4:12 in contexts which are related to some extent. ${ }^{115}$ Pericopes 2:8-13 and 4:11-12 are close to each other. Their similarity is based on related ter-

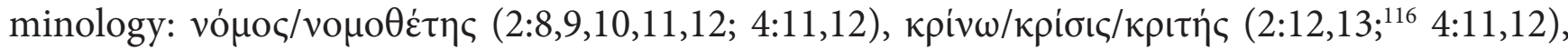
and $\pi \lambda$ n íov $(2: 8 ; 4: 12)$. In both cases, this terminology of law and court is used in connection with certain specific actions in the community of addressees: with favouring persons, or with slandering one another. Because in 4:11-12 the author moves quite smoothly from the use of

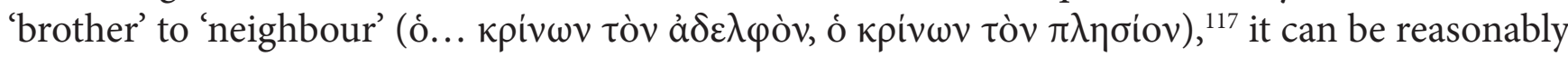
assumed that the contents of the two terms overlap to a large extent. A similar semantic overlap can also be inferred in sections 2:8-11 (13) where, as in 4:11-12, the addressees are addressed as 'brothers' (cf. 2:1,5; see also 2:14). To those the Old Testament citation of the command to love one's neighbour in 2:8 is addressed. ${ }^{118}$

The term åd $\delta \lambda \varphi$ ó $\varsigma$ is found in the Epistle of James 19 times in 17 verses $(1: 2,9,16,19 ; 2: 1,5,14,15$; $3: 1,10,12 ; 4: 11$ (3 times); 5:7,9,10,12,19), ${ }^{119}$ and the author uses it 15 times in the form of a plural vocative to address the addressees. It can therefore be stated that it is clearly applied to the members of the faithful community to which the Epistle is addressed. Whether the term $\pi \lambda \eta \sigma i o v$ applies only to the addressees addressed ${ }^{120}$ or should be understood in a broader, universal scope, ${ }^{121}$ cannot be unambiguously decided on the basis of just two occurrences. It applies especially if in one case it is an adopted Old Testament citation and in the other this term fluently alternates

114 Cf. Richard BAUCKHAM, James. Wisdom of James, disciple of Jesus the sage, London and New York: Routledge, 1999 , p. 145.

115 It cannot be completely ruled out that the author in 4:12 deliberately used the word $\pi \lambda \eta \sigma i o v$ as a reference to the commandment to love one's neighbour in 2:8. For example KONRADT, Love Command..., pp. 280-281; CHEUNG, Genre..., p. 122.

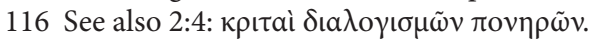

117 THEISSEN, Nächstenliebe..., p. 136: “Bruder” begegnet hier, weil von einem zwischenmenschlichen Verhältnis auf Gegenseitigkeit die Rede ist - von Menschen, die sich gegenseitig herabsetzen können $(4,11)$. "Nächster" begegnet in dem Augenblick, in dem vom Verhältnis zu Gott die Rede ist - als dem Richter, "der die Macht hat, zu retten und zu verderben" (4,12).

118 We see that the author of the Epistle does not avoid the term $\pi \lambda$ oíov, and he does not try to be consistent in using only the term "brother/brothers" (as is the case of the First Epistle of John where the word $\pi \lambda \eta \sigma i o v$ is not found at all). The same is true of the Gospel of John where the word $\pi \lambda \eta \sigma i o v$ is found only once (4:5) in the sense of a preposition meaning 'near'. For the meaning of this word, see TICHÝ, Slovník..., p. 139.

119 The feminine gender ả $\delta \varepsilon \lambda \varphi \eta$ is there only once in 2:15.

120 Within the specific situation described in 2:1-7, it can be quite rightly assumed that the author by 'neighbour' means mainly the 'poor' ( $\pi \tau \omega \chi \chi$ ó $)$. For example, Peter Wick, Zwischen Parteilichkeit und Barmherzigkeit! Jak 2,1-13 und die elaborierte Ethik des Jakobusbriefes, Annali di storia dell 'esegesi 2/2017, p. 450. On the other hand, even in James it is not possible to reduce 'neighbour' only to the 'poor'.

121 The view is held in particular by Gerd Theißen in his article Nächstenliebe und Egalität (see note 35). 


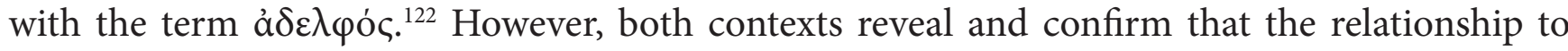
one's neighbour is fundamentally determined by and connected with subordination to the law, and with the recognition of its authority guaranteed by God himself. ${ }^{123}$

\section{You Do Right}

If the addressees of the Epistle fulfil the royal law in accordance with the commandment of

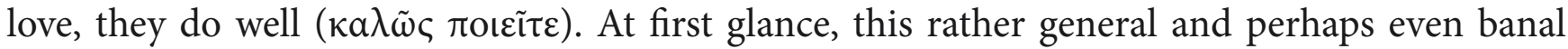
evaluation acquires a specifically important meaning in the context of the Epistle of James. It is mainly given by the fact that the verb $\pi$ otc่ $\omega$ ('to do, to act', etc.) ${ }^{124}$ is found 12 times in various, mostly theologically relevant contexts $(2: 8,12,13,19 ; 3: 12$ (2 times), 18; 4:13,15,17 (2 times); 5:15).

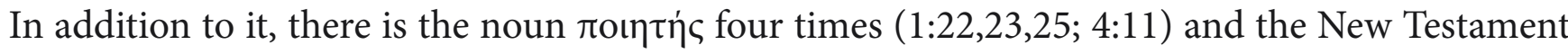

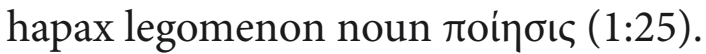

In verses $2: 12-13$, the verb $\pi$ oi $\varepsilon \omega$ is used in connection with the court: human speaking and

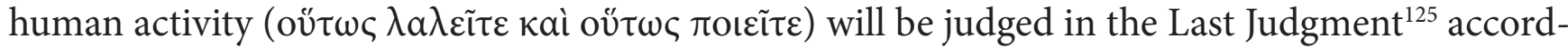

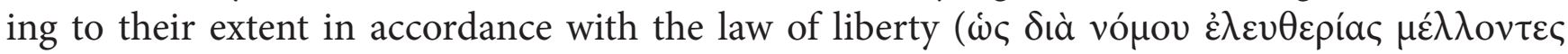

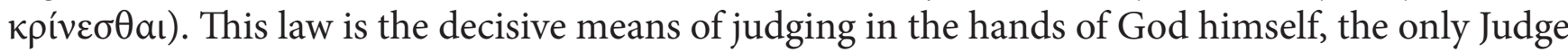
(cf. 4:12). According to 2:13, the fulfilment of the requirements of the law of liberty cannot be separated ( $\gamma \dot{\alpha} \rho)$ from the manifestations of mercy. Anyone who has not been merciful $(\tau \tilde{\omega} \mu \grave{\eta}$

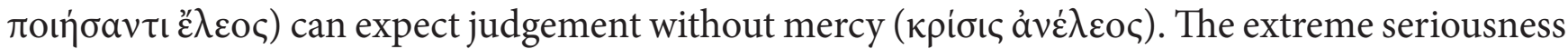
of this assertion comes to the fore when we consider the conclusion of verse 13 where mercy is

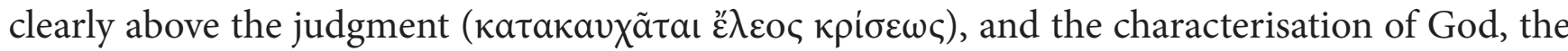
'only Judge' (4:12), who is already 'standing at the door' (5:9), in the verse 5:11 stating: 'The Lord

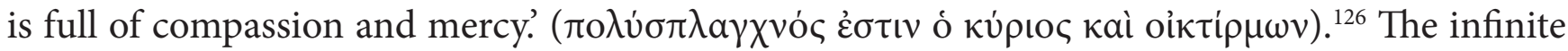
magnitude of God's mercy which is God's essential characteristic and quality, is limited (sit venia verbo) by the reluctance and inability of man to show mercy to one another. Because he is unable to deal with others mercifully, he is unable to accept God's mercy, ${ }^{127}$ and he excludes himself from its reach. As mentioned above, the theme of the law in 2:8-13 is framed by the commandment to love one's neighbour in verse 8 and mercy in verse 13. The manifestation of mercy is thus, or should be, one of the essential characteristic manifestations of the life of the believing community which fulfils the requirements of the law in accordance with the commandment to love one's neighbour. Verses 2:12-13, like 1:25, show very clearly the eschatological consequences of the present action.

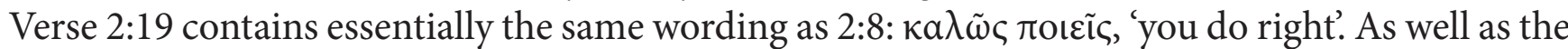
fulfilment of the royal law in accordance with the commandment to love one's neighbour, faith in the one God is also considered a good, or right 'act'. By itself, however, it is insufficient (кaì

122 ALLISON, Commentary..., p. 406: 'The inner-Jewish debate over how expansively to understand "neighbour" seems irrelevant for understanding James if all the parties concerned belong to the same synagogue (verses 1-7).

123 Cf. CHEUNG, Genre..., p. 123.

124 Cf. TICHÝ, Slovník..., p. 139.

125 Cain H. FELDER, Partiality and God's Law: An Exegesis of James 2:1-13, The Journal of Religious Thought 2/1982-1983, pp. 51-69, p. 68: 'If James does consider God to be the authoritative judge, then presumably James represents an imminent eschatological metaphor in 5:9c ("the judge stands at the door") in which the final judgment has God as the central figure. (...) When James 2:13a is considered

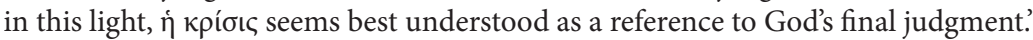

126 For more details, see the article Július PAVELČíK, „Velmi súcitný a lútostivý je Pán“ (Jak 5,11): K jednému aspektu Boha v Jakubovom liste, Studia Biblica Slovaca 1/2016, pp. 65-87.

127 Frank STAGG, Exegetical Themes in James 1 and 2, Review and Expositor 4/1969, p. 400: 'To lock another out is to lock oneself in. To reject mercy for other is to reject mercy for oneself.' 


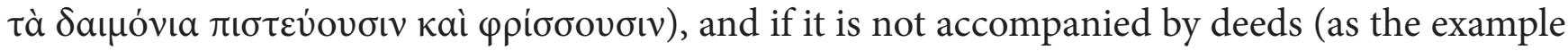

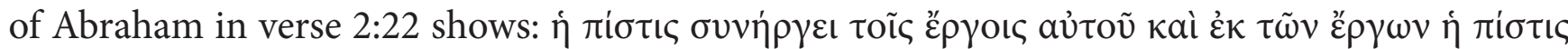

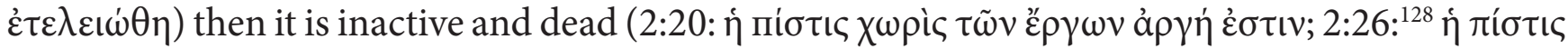

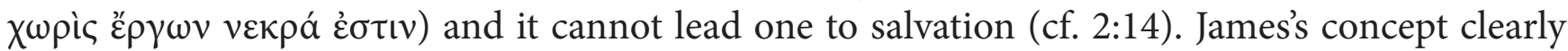
emphasises the soteriological relevance of a particular human action which is a manifestation and proof of the viability of faith in Jesus Christ (cf. 2:1).

The image used in 3:12 by the author of the Epistle in the form of a rhetorical question clearly demonstrates a certain unnaturalness of the dual use of language. As a fig tree cannot bear (literally 'do') olives and vines figs, and a salt spring cannot produce (literally 'do') fresh water, ${ }^{129}$ it is thus undesirable and unacceptable for man to bless God and at the same time curse man created in

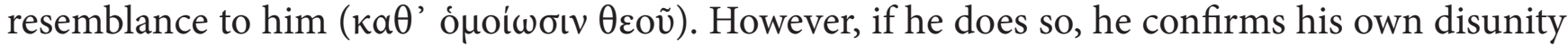
in himself (1:8: åvì $\rho \dot{i} \psi v \chi 0 \varsigma)$ in relation to God, just as the community in the Epistle of James

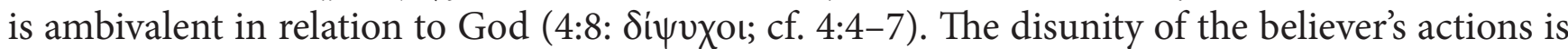
subsequently also reflected in the duality of his speech.

In the syntactically not entirely clear verse $3: 18,{ }^{130}$ the author speaks of those who 'make peace' ( $\tau$ io $\varsigma$

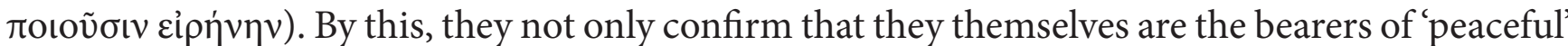



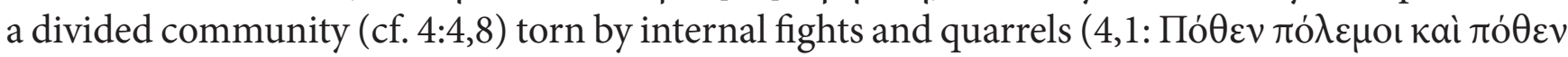

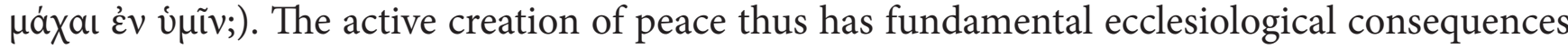
for the living and practical integrity of the community of believers.

In verses $4: 13$ and 15 , the verb $\pi$ oic่ $\omega$ is used in prosaic meanings: 'we will spend a year there'

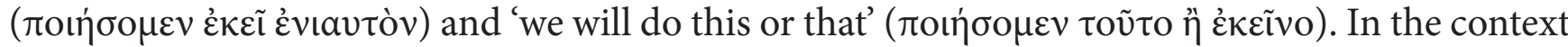
of verses 4:13-16, the author of the Epistle points out that no human activity especially the one re-

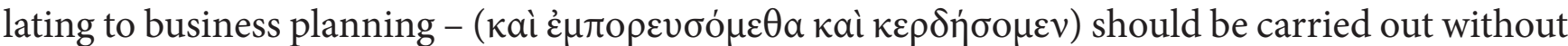

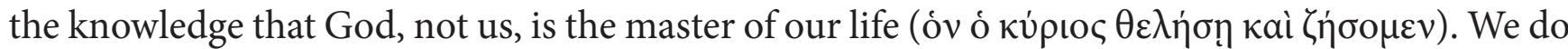
not even know what our tomorrow will look like, and we ourselves are just a 'mist' that will soon vanish (3:14). Human activity is simply existentially dependent on God's will.

As the 'firstfruits of creatures' born of the 'word of truth' by the decision of God's will (1:18), believers are called, among other things, to show their humble wisdom by the deeds of their 'good

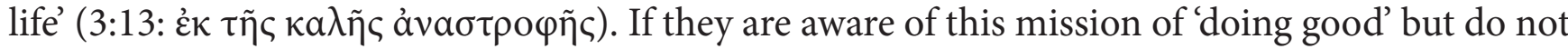

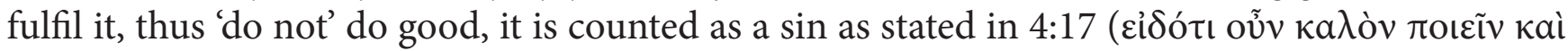

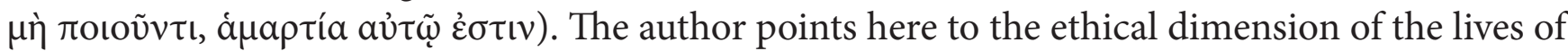
believers which carries with itself a commitment to do good in accordance with God's will. Sinful behaviour has serious negative soteriological consequences.

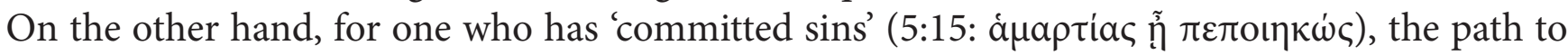
salvation is not definitively closed. According to the Epistle of James, the forgiveness of sins can be achieved within the community of addressees if they confess them to one another and pray for one another (5:16) because the prayer of faith has a saving potential (5:15). ${ }^{132}$ Each community

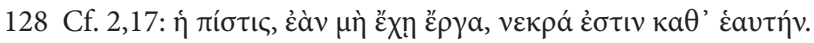

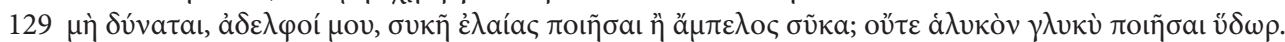

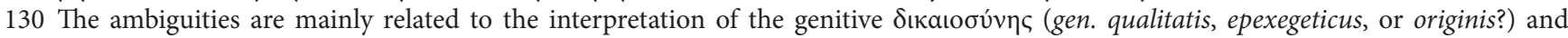

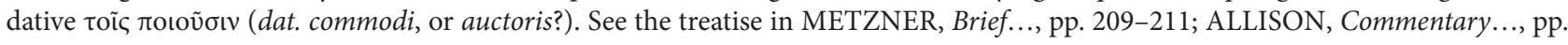
584-587.

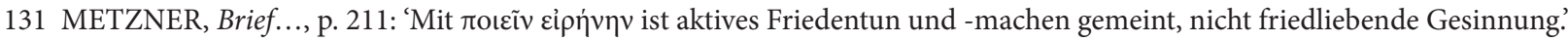

132 The verbs $\sigma \omega \dot{\omega} \zeta \omega$ and $\dot{\varepsilon} \gamma \varepsilon i \rho \omega$ used in verse 15 here have a basic meaning related to healing but in the context of the Christian faith they also point to a soteriological and eschatological aspect. The healing is perceived as an experience with God's power that raises the dead. The community is already experiencing it as a kind of anticipation of the eschatological renewal of the whole creation. 
member should seek to convert the sinner from his deceptive path. It will cover many of his sins and save him from death $(5: 20)$.

James 1:25 shows that the eschatological state of blessedness awaits everyone who acts steadfastly

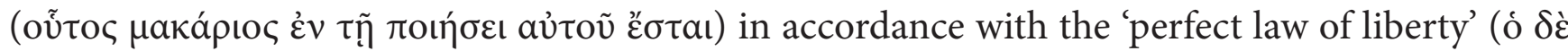

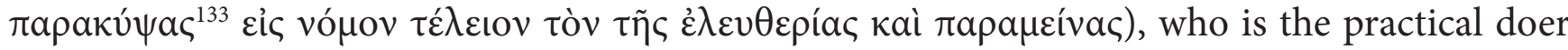

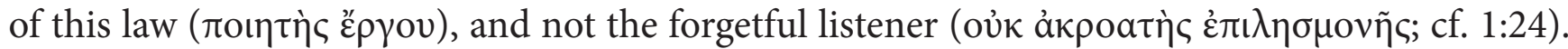
Since the law, according to the author of the Epistle, represents the imperative and binding aspect

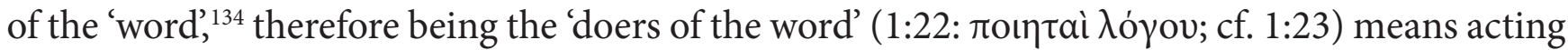
according to the word of salvation implanted in us (1:21b), and it also means being the doer of

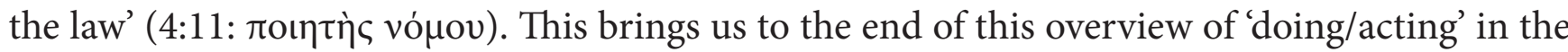

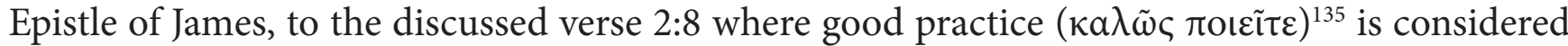
the doing or acting which fulfils the royal law in accordance with the commandment to love one's neighbour.

\section{Conclusion}

In the Epistle of James, the community with an ambivalent relationship to God is willing to submit to the 'world', its values and norms, and its morals (cf. 4:1-10). This state is also reflected in its inconsistent practical implementation of the commandment to love one's neighbour. According to the author of the Epistle, this manifests itself in a special way in favouring the rich. In this way they also transgress against the law which as a whole is the bearer of the royal, i.e., the highest dignity, and has a royal, i.e., decisive and definitive validity in the 'space' of the Kingdom of God. It is the norm set by the 'only one lawgiver' (4:12) in order to govern the whole life of the believing community. The main indicator in this is (for them) the Old Testament commandment to love one's neighbour (Leviticus 19:18) as shown by its introductory formula 'to fulfil the royal law according to Scripture' in 2:8. Love to one's neighbour, though not explicitly, is also inextricably linked with love to God in James. The term 'neighbour' in the context of the whole Epistle refers to all believers of the community of addressees. Its broader concept, though, which goes beyond the boundaries of that community cannot be completely ruled out.

In the context of the indisputable emphasis on the practical dimension of the Christian faith (confirmed both by the above remarks and by the well-known pericope 2:14-26 on the relationship between faith and deeds), it can be stated that love in the concept of the Epistle of James has, or should primarily have, the character of active ethical conduct. This acting should be focused ecclesiologically on building a community, soteriologically on the salvation of a person himself and of others, and eschatologically on being able to stand the Last Judgment in which the law plays a decisive role. Its particular implementation is judged according to the commandment to love one's neighbour. The law in James's conception is not an abstract or amorphous quality but (in the Jewish-Christian setting of the Epistle) it includes all the commandments of the Torah ${ }^{136}$ interpreted in the context of faith in Jesus Christ with special regard to the commandment of

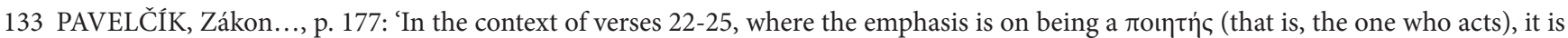

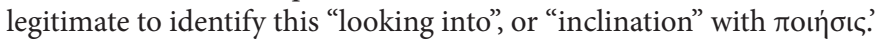

134 Cf. with the above p. 165.

135 HOPPE, Hintergrund..., p. 97: 'Voraussetzung zu solchem Handeln ist nach unserem Abschnitt das Erfüllen des ganzen Gesetzes, oder, um noch einmal auf 1,25 zurückzukommen, das Beharren im "vollkommenen Gesetz".

136 James's conception of the law is not limited to the Decalogue but also includes the ethical commandments of the Torah. Thus, the ritual regulations of Torah cannot be completely ruled out of this conception. See more on this in PAVELČÍK, Zákon..., pp. 205-206; PAVELČÍK, Nábožnost'..., pp. 25-26. 
love and mercy as decisive principles of action. In the narrower context of verses 2:1-13, love to one's neighbour is presented as the basis for equal treatment of the poor and the rich. If the community favours the rich, it follows principles other than the principle of love and is convicted of violating royal law by the same law that demands love. ${ }^{137}$

\section{Contact}

Dr. Julius Pavelčík

University of South Bohemia in České Budějovice

Faculty of Theology

Department of Theological Sciences

Kněžská 8, 37001 České Budějovice

pavelcik@tf.jcu.cz 